\title{
IMMUNOHISTOPATHOLOGICAL ROLE OF BCL2 AND P53 GENE EXPRESSION IN \\ HELICOBACTER PYLORI CYTOTOXIN-ASSOCIATED GENE A POSITIVE VERSUS CYTOTOXIN-ASSOCIATED GENE A NEGATIVE ANTRAL PREDOMINANT NON-ATROPHIC GASTRITIS IN IRAQI PATIENTS
}

\author{
ALI IBRAHIM ALI AL-EZZY* \\ Department of Pathology, College of Veterinary Medicine, Diyala University, Iraq. Email: alizziibrahim@gmail.com
}

Received: 11 October 2016, Revised and Accepted: 27 December 2016

ABSTRACT

Objectives: To determine the role of $\mathrm{Bcl} 2$ and p53 gene expression in the pathogenesis of antral-predominant non-atrophic gastritis (APNG) according to Helicobacter pylori (HP) cytotoxin-associated gene A (CagA) status.

Methods: Multiple antral biopsies were taken from 78 patients for rapid urease test, histopathology, Bcl2 and P53 immunohistochemistry and HP CagA in situ hybridization.

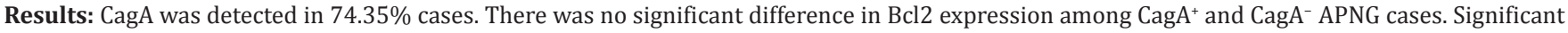

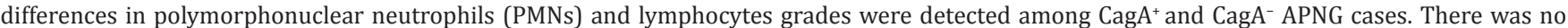
significant correlation among patients' age, inflammatory infiltrates, Bcl2, p53 expression. CagA has positive correlation with p53 ( $\mathrm{p}=0.001$ ), PMNs grade $(p=0.027)$, lymphocytes grade $(p=0.003)$, inflammation intensity $(p=0.006)$, and inflammation activity ( $p=0.007)$. Bcl 2 has no significant correlation with p53, CagA, PMNs, and lymphocytes indexes. P53 expression has significant correlation with PMNs and lymphocyte grades (p=0.000), inflammation intensity $(\mathrm{p}=0.003)$, and inflammation activity $(\mathrm{p}=0.002)$. PMNs grade has positive correlation with lymphocyte grade, inflammation intensity, and activity $(\mathrm{p}=0.000)$. Lymphocyte grade has a significant correlation with inflammation intensity and activity ( $\mathrm{p}=0.000)$. Inflammation intensity has a significant correlation with inflammation activity $(\mathrm{p}=0.000)$.

Conclusions: CagA cytotoxin has direct effect on P53 gene and indirect effect on Bcl2 gene expression in APNG cases. Bcl2 and P53 expression do not get affected by patient's age and gender. PMNs grade, lymphocytes grade, inflammation intensity, and inflammation activity affected directly by P53 and CagA cytotoxin expression and indirectly by Bcl2 expression. The balance of P53-Bcl2 pathways play a vital role in pathogenesis of HP and CagA-induced APNG.

Keywords: Antral-predominant non-atrophic gastritis, Bcl2, p53, Helicobacter pylori, Cytotoxin-associated gene A.

(C) 2017 The Authors. Published by Innovare Academic Sciences Pvt Ltd. This is an open access article under the CC BY license (http://creativecommons. org/licenses/by/4. 0/) DOI: http://dx.doi.org/10.22159/ajpcr.2017.v10i3.15622

\section{INTRODUCTION}

Antral-predominant non-atrophic gastritis (APNG) is the most common disorder of Helicobacter pylori (HP) gastritis in the Western world [1]. It is characterized by the absence of atrophy, moderate to severe inflammation in antrum, and a normal to mildly inflamed corpus with either normal or increased acid secretion [2]. Most patients with HP-associated gastritis are experienced no symptoms [3]. Cytotoxin-associated gene A (CagA) is non-conserved gene of HP which encodes a high (120-140 kDa) molecular weight immunodominant protein and present in up to $60 \%$ of H. pylori strains [4]. Infection with CagA-positive strains results in increased mucosal immune responses, more intense gastritis and highly associated with peptic ulcer, atrophic gastritis, and gastric cancer [5,6]. In addition to the direct immunological role, there is evidence that HP is associated with changes in epithelial cell turnover including the influence on apoptosis [7]. Apoptosis has an essential function in maintaining the integrity of the gastrointestinal mucosa. Several factors involved in regulating the equilibrium between apoptosis and proliferation include Bcl2 family proteins, p53, CD95 (Fas), and caspases. Neutrophil activation, oxidative stress, stress-induced protein genes, caspase 8 activation, the $\mathrm{Bcl} 2$ family, p53 transcription factor, and tumor necrosis factor-alpha may be involved in leading up to apoptosis [8]. Upregulation of apoptosis protectors $\mathrm{Bcl} 2$ proteins may supply cells with a survival advantage and hence play a role in carcinogenic pathway [9]. The expression of the antiapoptotic $\mathrm{Bcl} 2$ protein is enhanced in the case of gastric carcinoma and in the proliferative zone of gastric glands in the presence of chronic atrophic gastritis with intestinal metaplasia [10].

A transcription factor, p53 tumor suppressor gene, plays a vital role in counteract carcinogenesis and increase in p53 expression or p53 gene mutation is linked with suppression of cell cycle at G0 or G1 phase and does not permit entrance into the S phase, and in a secondary manner, does not let to damaged genome repairing. The arrest of cell cycle and thereafter apoptosis induction may be a result of p53 activation that inhibits cellular proliferation [11]. The role of p53 in pathogenesis of HP-associated gastritis is controversial; some studies have reported an elevation in p53 expression levels in HP-infected patients. In other side, some authors have reported that there is no difference in the levels of p53 expression and no association between HP infection and activation of p53 [12]. The presence of HP has been associated with increase in gastric epithelial apoptosis in vivo that returns to normal levels after eradication of the organism in most studies [13].

The objectives of this study were to determine the role of HP infection and CagA expression in Bcl2 and p53 gene expressions in APNG and to explain whether level of expression affected by inflammation activity, inflammation intensity, age, and gender of patients. 


\section{METHODS}

\section{Patients}

This study was conducted according to the Declaration of Helsinki. Duly filled consent form was obtained from all patients participating in the study before endoscopy. Approval of Ethical Review Committee of Pathology Department, Diyala University College of Veterinary Medicine, Iraq, was taken before initiation of the work. Seventy-eight patients with HP infection attending the gastroenterology unit of digestive and hepatic diseases teaching hospital in Baghdad were included. All patients fit to the inclusion criteria (above 18 years, both gender, suffering from symptoms of gastroesophageal reflux disease, acid peptic disease, dyspepsia, dysphagia, or comes for gastric cancer screening). According to exclusion criteria, patients were excluded from the study if had a history of gastric cancer, active hemorrhage, portal hypertension, undergone or were currently undergoing HP eradication therapy, received antiulcer treatment in the last three months, if patients did not sign letter of informed consent, if patients still receiving proton-pump inhibitors or $\mathrm{H} 2$ receptor blockers at the time of endoscopy, received nonsteroidal anti-inflammatory drugs in the 2 months before the examination, if the result of rapid urease test was negative [14].

\section{Samples preparation and scoring systems}

Multiple antral biopsies taken by upper gastrointestinal endoscopy from March 2012 to December 2013 were fixed in 10\% buffered formalin, paraffin-embedded, cut in serial $4 \mu \mathrm{m}$ sections, and stained with hematoxylin-eosin for histopathology. Gastritis and HP colonization were scored in accordance with the updated Sydney system [15]. This required the assessment of four variables (mononuclear cell infiltration intensity, inflammation activity, mucosal atrophy, and HP infection) on a 4-point scale ranging from negative (0), mild (1), moderate (2), to severe (3)

Chronic inflammation scores are as follows: 0 - none, mild $<10$ cells/hpf, moderate $>10$ cell/hpf to diffuse infiltration with dense chronic inflammatory cells, marked - nearly whole gastric mucosa contains dense chronic inflammatory cells. Inflammation activity is scored as follows: 0 - none (Grade 0), rare polymorphonuclear neutrophils (PMNs); 0-1 intraepithelial (IE) PMN/hpf, Grade (3): 1-10 IE PMN/(hpf), Grade (4): $\geq 10$ IE PMN/hpf, Grade (5): Pit abscess. Atrophy was scored as follows: 0: None, milde: Few to small area of gastric gland disappears or replaced by intestinal epithelium, moderate: $25-50 \%$ of gastric glands disappear or replaced, marked $>50 \%$ of gastric glands disappear or replaced. Intestinal metaplasia is scored as follows: None $=0$, milde: $1-4$ crypts are replaced by intestinal epithelium, moderate: Multiple foci of crypts in one or more biopsy are affected, marked: $>50 \%$ of gastric epithelia diffusely replaced. The density of HP was assessed semiquantitatively. HP density was scored as follows: None=no organisms, mild: Only few HP seen in single or multiple foci, moderate: Numerous HP seen in separated foci, marked: More than $50 \%$ of surface covered with HP.

One antral biopsy used for HP rapid urease test [16], other sections were stained immunohistochemically with monoclonal mouse anti human-Bcl2 oncoprotein and monoclonal mouse anti-human p53 Clone/REF: PAb240 detected by immunohistochemistry detection kit/DakoCytomation LSAB2 System-HRP (DakoCytomation, USA, code K0673) [17]. The expression of Bcl2 protein was measured by counting the number of positive cells with brown (diaminobenzidine [DAB]) cytoplasmic staining under light microscopy $\times 40$. For the evaluation of Bcl2 expression, a semi-quantitative evaluation system was used to record the number of positive cells. Bcl2 expression patterns were graded according to the classification of Xia et al. [18]. Negative result (Grade 0 ) estimated if $<5 \%$ of the cells were positively stained in contrast positive result estimated if $>5 \%$ of cells were positively stained. The positively stained cell arranged from low expression (Grade 1) if (5-25\%) of cells give positive signals; intermediate expression (Grade 2) if (26-50\%) of cells give positive signals, high expression (Grade 3) if $>50 \%$ of estimated cells give positive signals [18].
P53 protein expression was measured by counting the number of positive cells with brown (DAB) nuclear staining under light microscopy $\times 40$. For the evaluation of p53 expression, immunostaining was assessed semiquantitatively using a scoring system for both intensity and extent of staining [19]. Negative result (Grade 0 ) estimated if less than $10 \%$ of the cells were positively stained in contrast positive result estimated if more than $10 \%$ of cells were positively stained. The positively stained cell arranged from weak expression (Grade 1) if (10-30\%) of cells give positive signals; moderate expression (Grade 2) if (31-50\%) of cells give positive signals, high or intense expression (Grade 3) if more than $50 \%$ of estimated cells give positive signals.

Biotinylated DNA probes for HP CagA (HP/CagA Gene, Cat. No.: IH-60061, Maximbiotech product Catalog \# SP-10216) used for detection of expression using in situ hybridization technique [20]. The assessment was performed by two pathologists, independently and discordances were solved by consensus. The presence of CagA-positive HP was detected by direct visualization of bacteria with a characteristic blue-black color in gastric epithelial surface which reflect colonization with this pathogen [21].

\section{Statistical analysis}

Data analysis was performed using t-test to find out the significance of differences between continuous variables. Pearson test for correlation (R) used for non-categorical data. The level of significance was 0.05 (two-tail) in all statistical testing; significant of correlations include also 0.01 (two-tail). The level of confidence limits was 0.095 . Statistical analysis was performed using SPSS for Windows TM version 17.0, and Microsoft Excel for Windows 2010.

\section{RESULTS}

The patient's demographic characteristics are displayed in Table 1. Description of $\mathrm{Bcl} 2$, p53 expression is elucidated in Table 2. CagA was detected in $74.35 \%$ versus $25.64 \%$ CagA negative in APNG patients (Table 3 and Fig. 1). High level of gastric Bcl2 mRNA expression was detected in $12.82 \%$ CagA-positive versus $5.12 \%$ CagA-negative patients (Fig. 2). Intermediate expression was detected in $61.54 \%$ of CagA-positive versus (17.94\%) in CagA-negative patients. Low expression was not detected in CagA positive versus $(2.56 \%)$ CagA negative patients. There was no significant difference $(p=0.591399)$

Table 1: Demographic parameters for APNG patients

\begin{tabular}{lll}
\hline Demography & Parameters & APNG \\
\hline Age (years) & Minimum & 19 \\
& Maximum & 67 \\
& Mean \pm SD & $35.61 \pm 12.32$ \\
Gender (\%) & Male & $48(61.5)$ \\
& Female & $30(38.5)$ \\
Smoking (\%) & Smoker & $34(43.6)$ \\
& Non-smoker & $44(56.4)$ \\
Residence (\%) & Urban & $50(64.1)$ \\
& Rural & $28(35.9)$ \\
\hline
\end{tabular}

APNG: Antral predominant non-atrophic gastritis, SD: Standard deviation

Table 2: Description of Bcl2, p53 expression in APNG patients

\begin{tabular}{|c|c|c|c|c|}
\hline \multirow{2}{*}{$\begin{array}{l}\text { Positively } \\
\text { stained } \\
\text { cells (\%) }\end{array}$} & \multicolumn{2}{|l|}{ Bcl2 } & \multicolumn{2}{|l|}{ P53 } \\
\hline & $\begin{array}{l}\text { CagA } \\
\text { positive } \\
\text { APNG }\end{array}$ & $\begin{array}{l}\text { CagA } \\
\text { negative } \\
\text { APNG }\end{array}$ & $\begin{array}{l}\text { CagA } \\
\text { positive } \\
\text { APNG }\end{array}$ & $\begin{array}{l}\text { CagA } \\
\text { negative } \\
\text { APNG }\end{array}$ \\
\hline Minimum & 25 & 29 & 40 & 45 \\
\hline Maximum & 59 & 55 & 90 & 80 \\
\hline Mean $\pm S D$ & $43.76 \pm 9.36$ & $42.50 \pm 8.82$ & $70.59 \pm 12.73$ & $60.20 \pm 9.41$ \\
\hline T-test (p value) & 0.591399 & & 0.000357 & \\
\hline
\end{tabular}

APNG: Antral predominant non-atrophic gastritis, CagA: Cytotoxin associated gene A, SD: Standard deviation 
Table 3: Score of gastric Bcl2 and P53 expression in CagA positive versus CagA negative APNG patients

\begin{tabular}{|c|c|c|c|c|c|c|}
\hline \multirow[t]{3}{*}{ score } & \multicolumn{6}{|c|}{ Clinical presentation: APNG } \\
\hline & \multicolumn{3}{|l|}{$\mathrm{Bcl} 2$} & \multicolumn{3}{|l|}{ P53 } \\
\hline & $\begin{array}{l}\text { CagA positive } \\
\text { number }(\%)\end{array}$ & $\begin{array}{l}\text { CagA negative } \\
\text { number }(\%)\end{array}$ & Total (\%) & $\begin{array}{l}\text { CagA positive } \\
\text { number }(\%)\end{array}$ & $\begin{array}{l}\text { CagA negative } \\
\text { number }(\%)\end{array}$ & Total (\%) \\
\hline 0 & $0(0)$ & $0(0)$ & $0(0)$ & $0(0)$ & $0(0)$ & $0(0)$ \\
\hline 1 & $0(0)$ & $2(2.56)$ & $2(2.56)$ & $0(0)$ & $0(0)$ & $0(0)$ \\
\hline 2 & $48(61.54)$ & $14(17.94)$ & $62(79.48)$ & $8(10.26)$ & $2(2.56)$ & $10(12.82)$ \\
\hline Total & $58(74.35)$ & $20(25.64)$ & $78(100)$ & $58(74.35)$ & $20(25.64)$ & $78(100)$ \\
\hline T-test ( $\mathrm{p}$ value) & 0.591399 & & & 0.000357 & & \\
\hline
\end{tabular}

APNG: Antral predominant non-atrophic gastritis, CagA: Cytotoxin associated gene A

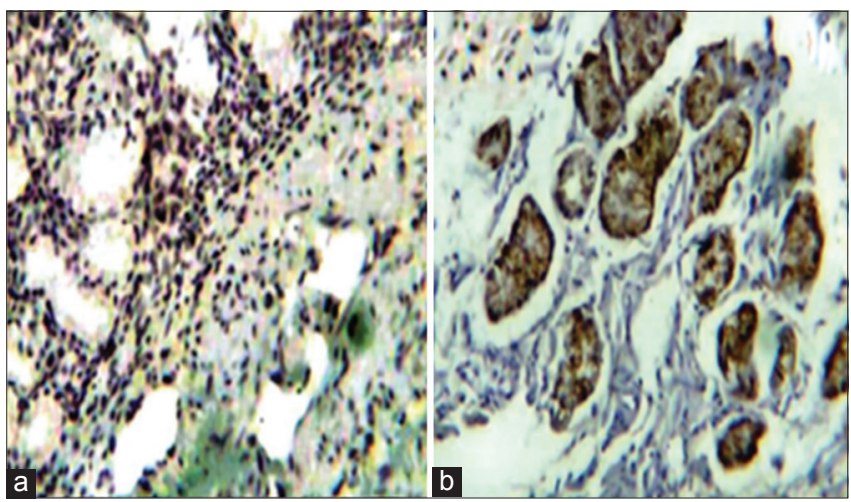

Fig. 1: In situ hybridization for cytotoxin-associated gene A positive Helicobacter pylori in gastric tissue section stained with diaminobenzidine and counterstained with hematoxylin. (a) Positive. (b) Negative. Bar size $50 \mu \mathrm{m}$

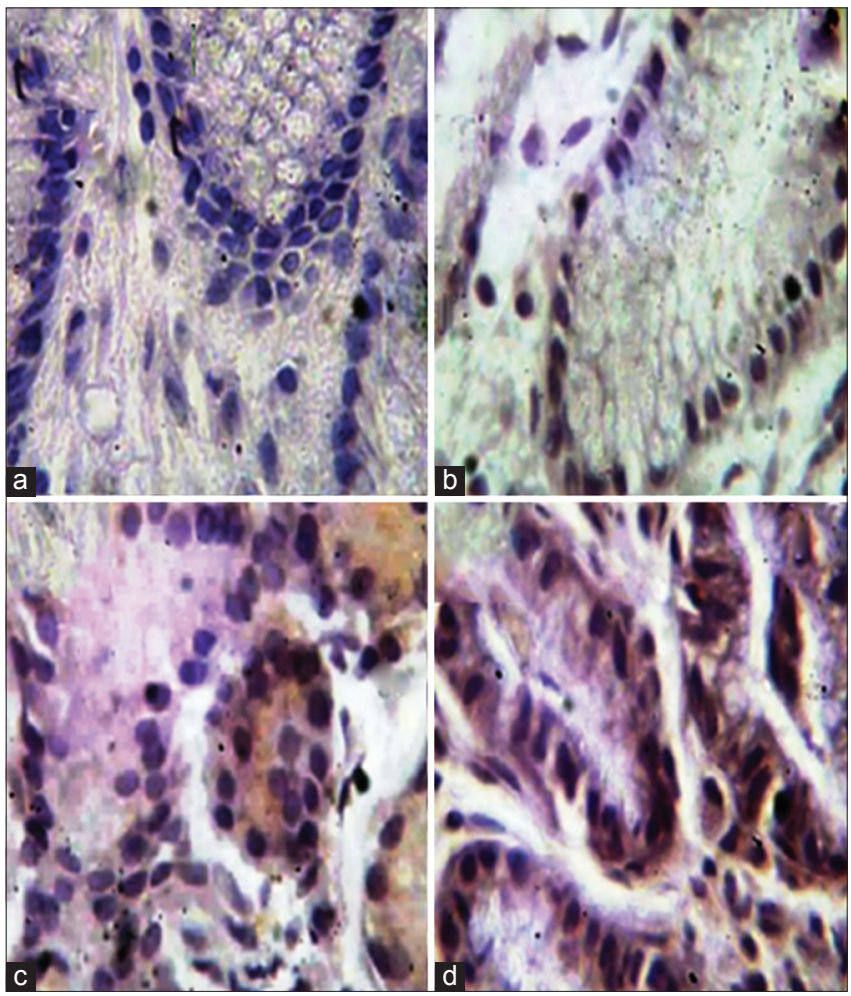

Fig. 2: Immunohistochemical staining of $\mathrm{Bcl} 2$ in gastric tissue section. Diaminobenzidine cytoplasmic staining (brown) counterstained by hematoxylin. (a) No staining. (b) Slight staining. (c) Moderate staining. (d) Substantial staining. Bar size $50 \mu \mathrm{m}$ in Bcl2 mRNA expression between CagA positive and CagA negative patients (Table 3$)$. There is a significant difference $(p=0.000357)$ in $p 53$ mRNA expression between CagA-positive versus CagA-negative APNG patients (Table 3 and Fig. 3).

Moderate lymphocytes intensity within the lamina propria was identified in (30.77\%) CagA-positive APNG compared with $10.26 \%$ among CagA-negative cases. Heavy lymphocytes intensity detected in 43.59\% CagA-positive compared with $15.38 \%$ among CagA-negative cases. Significant differences between CagA-positive and CagA-negative APNG cases in lymphocytes intensity $(\mathrm{p}=0.02134)$ as in Table 4. IE PMNs 1-10/(hpf) (Grade 3) within the lamina propria detected in $30.77 \%$ of APNG with CagA positive HP compared with $10.26 \%$ among CagA negative cases (Grade 4) $\geq 10$ IE PMN/hpf detected in $43.59 \%$ of APNG with CagA positive HP compared with $15.38 \%$ among CagA negative cases. Significant differences in inflammation activity between CagA positive and CagA negative APNG ( $p=0.022309)$ (Table 4). No atrophy and intestinal metaplasia were detected in all cases. HP density was mild in $20.51 \%$, moderate in $44.87 \%$, and marked in $34.61 \%$.

No significant correlation among patients age, inflammatory infiltrates, $\mathrm{Bcl} 2$, and p53 expression. Gender has positive correlation with smoking $(p=0.001)$ and negative correlations with PMNs grades $(p=0.032)$, lymphocytes grades $(\mathrm{p}=0.012)$, inflammation intensity $(\mathrm{p}=0.042)$. CagA has positive correlation with $\mathrm{p} 53(\mathrm{p}=0.001)$, PMNs grades $(\mathrm{p}=0.027)$, lymphocytes grades $(p=0.003)$, inflammation intensity $(p=0.006)$, and inflammation activity $(\mathrm{p}=0.007)$. Bcl 2 has no significant correlation with p53, CagA, PMNs, lymphocytes indexes. p53 expression has significant positive correlation with PMNs grades and lymphocyte grades $(p=0.000)$, inflammation intensity $(p=0.003)$, inflammation activity $(p=0.002)$. Smoking has negative correlation $(p=0.000)$ with PMNs and lymphocyte grades, inflammation intensity, inflammation activity. PMNs grades have positive correlation with lymphocyte grades, inflammation intensity, inflammation activity $(\mathrm{p}=0.000)$. Lymphocyte grades have positive correlation with inflammation intensity $(\mathrm{p}=0.000)$. Inflammation activity has positive correlation with inflammation activity and lymphocyte grades $(\mathrm{p}=0.000)$ (Table 5).

\section{DISCUSSION}

In this study, the prevalence of HP infection among APNG patients was mainly in those at mid third decade of age. This may be due to the possible role for the mode of transmission and general healthy practice in developing countries in which $90 \%$ of population with age of adulthood are infected $[1,22,23]$. In this study, an excess of HP prevalence was reported in males. Gender differences in HP-induced gastroduodenal diseases may reflect study design effects, nature of community under investigation, differences in immune responses, hormonal effects, and sex-linked genetic factors and differences in bacterial colonization [24,25]. In the present study, colonization of HP CagA+/urease + in gastric tissue was determined in $74.35 \%$ of cases versus $25.64 \%$ HP CagA-/urease + was distinguished and come in line with others $[26,27]$. This finding suggests that the pathogenic potential of HP strains on the gastric mucosa may be exerted in full only when 


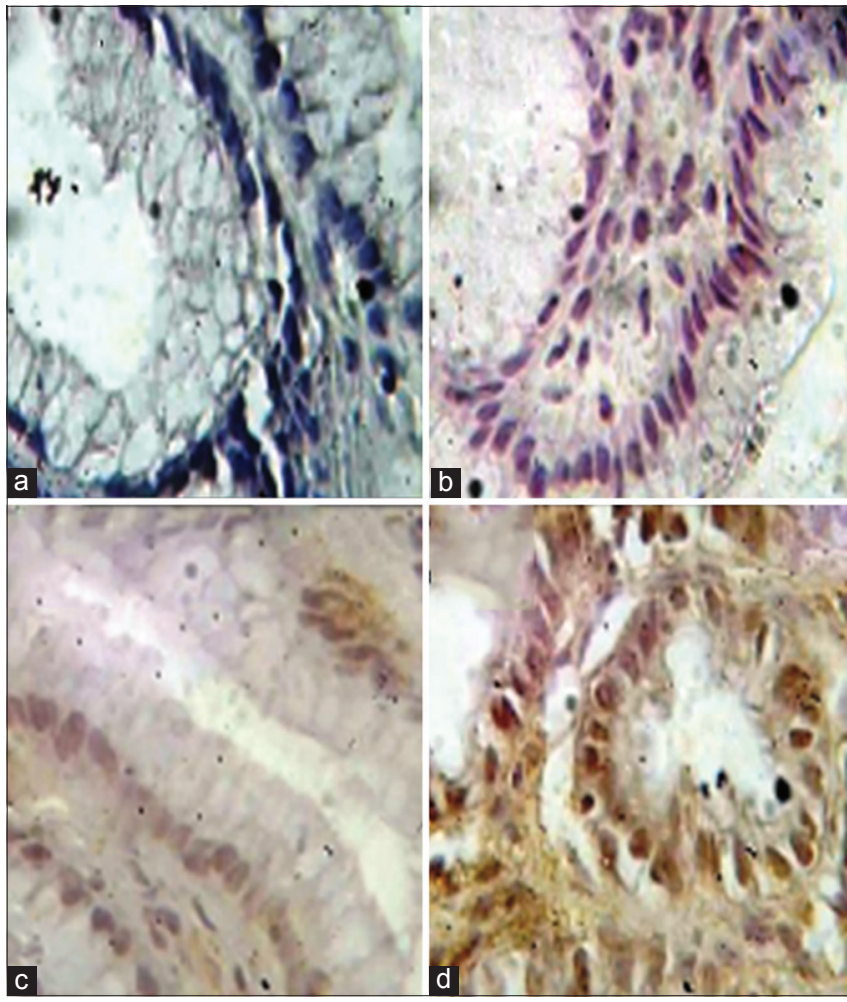

Fig. 3: Immunohistochemical staining of p53 in gastric tissue section $(\times 40)$. Diaminobenzidine nuclear and perinuclear staining (brown) counterstained by hematoxylin. (a) No staining,

(b) weak staining, (c) moderate staining, (d) strong staining

CagA + colonies make up the majority of the organisms colonizing a particular gastric area [28]. This study comes in accordance with others that which stated that there was no significant correlation between patients age, gender, and HP infection despite the ability to produce CagA cytotoxin [29]. In this study, the prevalence of HP was lower in rural than urban regions which come in concordance with records from Thailand, Vietnam, and Greece [30,31].

In this study, chronic inflammation intensity expressed by moderate to heavy lymphocytes and PMNs intensity within the lamina propria were observed which come in agreement with others [32-35], significant difference in inflammation activity grades and in inflammation intensity grades between CagA positive versus CagA negative APNG patients were detected. Significant correlations were detected between HP CagA, inflammation activity grades, and inflammation intensity grades that come in line with others stated that significant correlation was found between HP density and the grade of acute and chronic inflammation $[36,37]$.

The possible mechanism for moderate to heavy lymphocytes and PMNs intensity within the lamina propria determined in this study may attributed to the availability of different HP adhesins proteins (BabA) and (SabA) that have the ability to binds with fucosylated antigens (Leb, A Leb, B Leb) on healthy gastric epithelial cells and inflammationassociated sialylated glycans such (i.e., sLex and sLea) that increased in its expression during the course of infection [38]. HP attachment to gastric epithelial cells activates HP type IV secretion system, which leads to injection of Cag PAI effector proteins into host cells, mainly CagA cytotoxin [39] that lead to upregulation of inflammatory genes such as proinflammatory cytokines, receptors, chemokines and their receptors, genes responsible for apoptosis process, and adhesion molecules. Upregulation of nuclear factor $\kappa \mathrm{B}(\mathrm{NF}-\kappa \mathrm{B})$ the activity as transcriptional factor was takes place, which, together with AP-I, leads to induction of interleukin (IL)-8 expression [40]. In response to
Table 4: Score of APNG patients according to updated Sydney system

\begin{tabular}{|c|c|c|}
\hline \multirow[t]{2}{*}{ Parameters } & \multicolumn{2}{|c|}{$\begin{array}{l}\text { Helicobacter pylori } \\
\text { associated APNG }\end{array}$} \\
\hline & $\begin{array}{l}\text { CagA } \\
\text { positive }\end{array}$ & $\begin{array}{l}\text { CagA } \\
\text { negative }\end{array}$ \\
\hline \multicolumn{3}{|l|}{ Chronic inflammation intensity } \\
\hline No inflammation (Grade 0) & $0(0 \%)$ & $0(0 \%)$ \\
\hline Mean score \pm SD & $0 \pm 0.00$ & $0 \pm 0.00$ \\
\hline Low inflammation (Grade 1) & $0(0 \%)$ & $0(0 \%)$ \\
\hline Mean score \pm SD & $0 \pm 0.00$ & $0 \pm 0.00$ \\
\hline Moderate inflammation (Grade 2) & $24(30.77 \%)$ & $8(10.26 \%)$ \\
\hline Mean score \pm SD & $5 \pm 3.97$ & $3 \pm 1.31$ \\
\hline Heavy inflammation (Grade 3) & $34(43.59 \%)$ & $12(15.38 \%)$ \\
\hline Mean score $\pm S D$ & $18.47 \pm 1.11$ & $11.5 \pm 0.52$ \\
\hline T-test (p value) & 0.02134 & \\
\hline \multicolumn{3}{|l|}{ Inflammation activity } \\
\hline Grade 0 & $0(0 \%)$ & $0(0 \%)$ \\
\hline Mean score $\pm S D$ & $0 \pm 0.00$ & $0 \pm 0.00$ \\
\hline Grade 1 & $0(0 \%)$ & $0(0 \%)$ \\
\hline Mean score \pm SD & $0 \pm 0.00$ & $0 \pm 0.00$ \\
\hline Grade 2 & $0(0 \%)$ & $0(0 \%)$ \\
\hline Mean score \pm SD & $0 \pm 0.00$ & $0 \pm 0.00$ \\
\hline Grade 3 & $24(30.77 \%)$ & $8(10.26 \%)$ \\
\hline Mean score \pm SD & $4.83 \pm 4$ & $3 \pm 1.51$ \\
\hline Grade 4 & $34(43.59 \%)$ & $12(15.38 \%)$ \\
\hline Mean score $\pm S D$ & $18.29 \pm 1.29$ & $11.33 \pm 0.49$ \\
\hline Grade 5 & $0(0 \%)$ & $0(0 \%)$ \\
\hline T test ( $\mathrm{p}$ value) & 0.022309 & \\
\hline \multicolumn{3}{|l|}{ Atrophy } \\
\hline Nil (0) & $78(100 \%)$ & \\
\hline Mild (1) & $0(0 \%)$ & \\
\hline Moderate (2) & $0(0 \%)$ & \\
\hline Marked (3) & $0(0 \%)$ & \\
\hline \multicolumn{3}{|l|}{ Intestinal metaplasia } \\
\hline Nil (0) & $78(100 \%)$ & \\
\hline Mild (1) & $0(0 \%)$ & \\
\hline Moderate (2) & $0(0 \%)$ & \\
\hline Marked (3) & $0(0 \%)$ & \\
\hline \multicolumn{3}{|l|}{ Helicobacter pylori density } \\
\hline Nil (0) & $0(0 \%)$ & \\
\hline Mild (1) & $16(20.51 \%)$ & \\
\hline Moderate (2) & $35(44.87 \%)$ & \\
\hline Marked (3) & $27(34.61 \%)$ & \\
\hline
\end{tabular}

APNG: Antral predominant non-atrophic gastritis, CagA: Cytotoxin associated gene A, SD: Standard deviation

IL-8 chemotactic gradient and activating peptide produced by gastric epithelial cells, HP neutrophils activating protein (HP-NAP) and urease, neutrophils, macrophages, and lymphocytes start to migrate toward infection site. HP and inflammatory infiltrates start to produce oxidative stress in gastric microenvironment. HP-NAP stimulates (nicotinamide adenine dinucleotide) oxidase assembly and production of reactive oxygen species [41]. Neutrophils express the myeloperoxidase enzyme, which produces a powerful oxidant hypochlorous anion $\left(\mathrm{OCl}^{-}\right)$from $\mathrm{H}_{2} \mathrm{O}_{2}$ in the existence of $\mathrm{Cl}^{-}$. Ammonia that produced from the activity of HP urease on urea, react with hypochlorous anion reacts to produce monochloramine $\left(\mathrm{NH}_{2} \mathrm{Cl}\right)$, the lipophilic cytotoxic oxidant which freely penetrates gastric epithelial cells membranes to oxidize intracellular components and produce DNA damage. On the other hand, CagA was shown to induce spermine oxidase in gastric epithelial cells and produce $\mathrm{H}_{2} \mathrm{O}_{2}$ that leads to apoptosis, and DNA damage during infection [42]. Moderate to heavy lymphocytic infiltration detected in the present study supports the suggestion that HP is capable of invading gastric mucosal epithelial cells [43] and gastric epithelia continuously exposes to oxidative stress due to HP CagA, urease and other products causing induction of NF- $\mathrm{KB}$ that enhance inflammatory reaction by a network of cytokines and chemokines for attraction of different immunocytes to gastric epithelia and induce their activation [44]. 
Table 5: Correlations among different markers used in the present study

\begin{tabular}{|c|c|c|c|c|c|c|c|c|c|}
\hline Parameters & Gender & Smoking & CagA & Bcl2 & p53 & $\begin{array}{l}\text { PMNs } \\
\text { grade }\end{array}$ & $\begin{array}{l}\text { Inflammation } \\
\text { activity }\end{array}$ & $\begin{array}{l}\text { Lymphocyte } \\
\text { grade }\end{array}$ & $\begin{array}{l}\text { Inflammation } \\
\text { intensity }\end{array}$ \\
\hline Age & 0.087 & -0.032 & -0.033 & 0.034 & -0.104 & 0.020 & -0.002 & -0.032 & -0.049 \\
\hline $\begin{array}{l}\mathrm{r} \\
\mathrm{p} \text { value }\end{array}$ & 0.448 & 0.784 & 0.775 & 0.767 & 0.363 & 0.864 & 0.987 & 0.779 & 0.671 \\
\hline Gender & & $0.376^{* *}$ & 0.019 & -0.072 & 0.062 & $-0.243^{*}$ & -0.203 & $-0.284^{*}$ & $-0.231 *$ \\
\hline $\begin{array}{l}\mathrm{r} \\
\mathrm{p} \text { value }\end{array}$ & & 0.001 & 0.872 & 0.531 & 0.591 & 0.032 & 0.075 & 0.012 & 0.042 \\
\hline $\begin{array}{l}\mathrm{r} \\
\mathrm{p} \text { value }\end{array}$ & & & 0.159 & 0.679 & 0.493 & 0.000 & 0.000 & 0.000 & 0.000 \\
\hline CagA & & & & 0.060 & $0.358^{* *}$ & $0.250^{*}$ & $0.301^{* *}$ & $0.337^{* *}$ & $0.306^{* *}$ \\
\hline $\begin{array}{l}\mathrm{r} \\
\mathrm{p} \text { value }\end{array}$ & & & & 0.600 & 0.001 & 0.027 & 0.007 & 0.003 & 0.006 \\
\hline $\mathrm{Bcl} 2$ & & & & & 0.192 & -0.004 & 0.011 & 0.077 & 0.031 \\
\hline $\begin{array}{l}\mathrm{r} \\
\mathrm{p} \text { value }\end{array}$ & & & & & 0.092 & 0.972 & 0.925 & 0.502 & 0.785 \\
\hline $\begin{array}{l}\mathrm{r} \\
\mathrm{p} \text { value }\end{array}$ & & & & & & 0.000 & 0.002 & 0.000 & 0.003 \\
\hline $\begin{array}{l}\text { PMNs grade } \\
\mathrm{r} \\
\mathrm{p} \text { value }\end{array}$ & & & & & & & $\begin{array}{l}0.792^{* *} \\
0.000\end{array}$ & $\begin{array}{l}0.950^{* *} \\
0.000\end{array}$ & $\begin{array}{l}0.806^{* *} \\
0.000\end{array}$ \\
\hline $\begin{array}{l}\text { Inflammation activity } \\
\mathrm{r} \\
\mathrm{p} \text { value }\end{array}$ & & & & & & & & $\begin{array}{l}0.856^{* *} \\
0.000\end{array}$ & $\begin{array}{l}0.987^{* *} \\
0.000\end{array}$ \\
\hline $\begin{array}{l}\text { Lymphocytes grade } \\
\text { r } \\
\text { p value }\end{array}$ & & & & & & & & & $\begin{array}{l}0.871^{* *} \\
0.000\end{array}$ \\
\hline
\end{tabular}

${ }^{*}$ Correlation is significant at the 0.05 level (2-tailed), ${ }^{* *}$ Correlation is significant at the 0.01 level (2-tailed). PMNs: Polymorphonuclear neutrophils, CagA: Cytotoxin associated gene $\mathrm{A}$

In this study, moderate Bcl2 expression (61.54\%) and marked P53 expression (64.10\%) among CagA positive APNG cases were recorded. There was no significant difference in Bcl2 expression in gastric tissue despite the CagA positivity. A significant difference in p53 mRNA expression between CagA positive versus CagA negative APNG patients was reported. The possible mechanism of moderate Bcl2 expression versus marked P53 expression is due to the fact that as a result of HP infection, its cytotoxins, oxidative stress and inflammatory cytokines in gastric microenvironment leads to activation of P53 expression to exert anti-inflammatory, DNA repair, cell cycle regulation and regulation of apoptotic process as well as NF- $\mathrm{kB}$. In gastric epithelial cells under stress, anti-apoptotic Bcl2 proteins produce via activation of NF-KB as well as scavenging of free radicals started to protect cells from harsh conditions [44]. On the other hand, another transcription factor activated, which is a P53 that play a dual function, in the nucleus to induce cell cycle arrest and apoptosis following a genotoxic stress and "extranuclear," proapoptotic function as a result of binding to Bcl-XL or Bcl2 located in the outer mitochondrial membrane [45]. P53 executes its effects on intrinsic apoptotic pathway via Bax, apaf-1, and casp-9. p53 is a direct transcription activator of the human Bax gene which is a member of pro-apoptotic class of Bcl2 family [46]. p53 can directly disrupt the Bcl2/Bax complex by binding to a novel regulatory region of Bcl2's flexible loop domain (aa 32-68) which known as a "negative" regulatory domain in $\mathrm{Bcl} 2$ [45]. The consequence of this interaction is the release of proapoptotic Bax that is "peripherally" associated with mitochondria to become integrally associated in the outer mitochondrial membrane leading to cytochrome c release, it binds together with dATP and apoptosis activity factor-1 to procaspase-9, resulting in the activation of downstream caspases that induces proteolytic processing and activation of cell death [47], which explain the current finding of the positive correlation of p53 expression with increase of gastric apoptotic index \% in CagA positive patients. This explanation comes in accordance with other studies [19,48-51], stated a significant association between HP infection and the expression of Bax which leads to gastric epithelium apoptosis through upregulation of Bax and downregulation of Bcl2. Other stated that HP induces apoptosis in the gastric epithelium through downregulation of the $\mathrm{Bcl} 2$ and upregulation of Bax as well as other Bcl2 family proteins such as $\mathrm{Bcl}-\mathrm{xL}$ and Bak at transcriptional and protein levels under the NF- $\mathrm{KB}$ regulations, whether HP express or not the CagA oncoprotein [52]. Eventually, CagA positive strains cause much more severe lesions at the site of infection by increasing the apoptotic process [53]. The balance between Bax and Bcl2 is known to regulate apoptosis [51]. The apoptotic pathways induced by HP activate Bax, disrupt mitochondrial integrity, and are abrogated by Bcl2 [18]. The expression of Bcl2 in the present study could be explained as forced expression to protect the mitochondria of gastric epithelial cells.

A significant difference in inflammation activity grades as well as in inflammation intensity grades between CagA positive versus CagA negative APNG patients which come in accordance with others $[37,54]$. Chronic inflammation due to persistent HP infection expected to cause repetitive degeneration and regeneration of the mucosal epithelium that could facilitate malignant transformation. While epithelial cell proliferation is not carcinogenic in itself, it is likely to promote neoplastic transformation in combination with additional factors, such as genetic alterations and oncoprotein overexpression [55].

The current study found no correlation between inflammation scores and Bcl2 expression which come in line with Lynch et al. [56], Kohda et al. [57] and which disagree with Rokkas et al. [58]. Significant correlations between CagA, P53, smoking, inflammation activity grades, inflammation intensity grades were detected which agree with that reported by Suzuki et al. [59] Robinson et al. [60]. They found significant correlation between inflammation scores and apoptosis and this give an important suggestion that CagA positive HP strains had the ability to induce high levels of p53 expression and inflammation more than those which are CagA negative. The possible correlation between CagA, P53, and smoking related to induction of NFKB expression and subsequently inflammatory response associated with production of oxidative stress and induction of apoptotic process which end by DNA fragmentation and atrophy of group of cells [53]. These inconsistencies 
are not explained by study designs, or by the endoscopic findings or clinical details of the patient's studies in previous studies. The lack of a clear correlation between inflammation and apoptosis, therefore, suggests that the inflammatory response is not important in determining the extent of epithelial apoptosis in response to HP in vivo or that the measurement of the inflammatory response to HP by histological criteria alone does not adequately reflect pro-apoptotic inflammatory stimuli present in the HP colonized gastric mucosa.

In conclusion, CagA cytotoxin has direct effect on P53 gene and indirect effect on Bcl2 gene expression in APNG cases. Bcl2 and p53 expression do not affect by patient's age and gender. PMNs grade, lymphocytes grade, inflammation intensity and inflammation activity affected directly by P53 and CagA cytotoxin expression and indirectly by Bcl2 expression. The balance of P53-Bcl2 pathways plays a vital role in pathogenesis of HP and CagA-induced APNAG.

\section{REFERENCES}

1. Al-Ezzy AI. Evaluation of clinicopathological and risk factors for nonmalignant $H$. Pylori associated gastroduodenal disorders in iraqi patients. Open Access Maced. J Med Sci 2015;3(4):645-54.

2. Rugge M, Genta RM. Staging and grading of chronic gastritis. Hum Pathol 2005;36(3):228-33.

3. Watari J, Chen N, Amenta PS, Fukui H, Oshima T, Tomita T, Miwa H, Lim KJ, Das KM. Helicobacter pylori associated chronic gastritis, clinical syndromes, precancerous lesions, and pathogenesis of gastric cancer development. World J Gastroenterol 2014;20(18):5461-73.

4. Paniagua GL, Monroy E, Rodríguez R, Arroniz S, Rodríguez C, Cortés JL, Camacho A, Negrete E, Vaca S. Frequency of vacA, cagA and babA2 virulence markers in Helicobacter pylori strains isolated from Mexican patients with chronic gastritis. Ann Clin Microbiol Antimicrob 2009;8(1):14.

5. Müller A, Oertli M, Arnold IC. H. Pylori exploits and manipulates innate and adaptive immune cell signaling pathways to establish persistent infection. Cell Commun Signal 2011;9(1):25.

6. Al-Ezzy AI. Molecular and immunopathological role of gastric versus lymphocytes interleukin 8 gene expression in $H$. Pylori induced fasfasl apoptotic pathway in gastroduodenal ulcer in Iraqi patients. J Biol, Agric Healthe 2015;5(5):141-53.

7. Kim SS, Ruiz VE, Carroll JD, Moss SF. Helicobacter pylori in the pathogenesis of gastric cancer and gastric lymphoma. Cancer Lett 2011 28:305(2):228-38.

8. Gucin Z, Akmak T, Bayyurt N, Salih B. Helicobacter pylori infection and relationship with gastric epithelial cell proliferation and apoptosis. Turk Med Sci 2013:43(5):739-46.

9. Shiotani A, Iishi H, Ishiguro S, Tatsuta M, Nakae Y, Merchant JL. Epithelial cell turnover in relation to ongoing damage of the gastric mucosa in patients with early gastric cancer: Increase of cell proliferation in paramalignant lesions. J Gastroenterol 2005;40(4):337-44.

10. Targa A, Cesar A, Cury P, Silva A. Apoptosis in different gastric lesions and gastric cancer: Relationship with Helicobacter pylori, overexpression of 53 and aneuploidy. Genet Mol Res 2007;6(3):554-65.

11. Wei J, O'Brien D, Vilgelm A, Piazuelo MB, Correa P, Washington MK, et al. Interaction of Helicobacter pylori with gastric epithelial cells is mediated by the p 53 protein family. Gastroenterology 2008;134(5):1412-23.

12. Wei JN, Vilgelm A, Zaika E, Ogden SR, Romero-Gallo J, Piazuelo MB, et al. Regulation of p53 tumor suppressor by Helicobacter pylori in gastric epithelial cells. Gastroenterology 2010;139(4):1333-43.

13. Bimczok D, Smythies LE, Waites KB, Grams JM, Stahl RD, Mannon PJ, et al. Helicobacter pylori infection inhibits phagocyte clearance of apoptotic gastric epithelial cells. J Immunol 2013;190(12):6626-34.

14. Al-Ezzy AI. Immunopathological role of FAS-FASL apoptotic pathway in H. Pylori CagA positive associated chronic atrophic gastritis in Iraqi patients. J Biol Agric Healthc 2014;4(23):67-4.

15. Stolte M, Meining A. The updated Sydney system: Classification and grading of gastritis as the basis of diagnosis and treatment. Can J Gastroenterol 2001;15(9):591.

16. Forbes B, Sahm D, Weissfeld A, editors. Bailey and Scott Diagnostic Microbiology. St. Louis, MO: Mosby; 2002.

17. Immunohistochemistry Detection Kit LSAB2 System-HRP. Available from: http://www.dako.com/dist/ar38/pg719/productsubgroups.htm.

18. Xia HH, Zhang GS, Talley NJ, Wong BC, Yang Y, Henwood C, et al. Topographic association of gastric epithelial expression of Ki-67, Bax, and $\mathrm{Bcl}-2$ with antralization in the gastric incisura, body, and fundus. Am J Gastroenterol 2002;97(12):3023-31.

19. Teh M, Tan KB, Seet BL, Yeoh KG. Study of p53 immunostaining in the gastric epithelium of cagA positive and cagA negative Helicobacter pylori gastritis. Cancer 2002;95(3):499-505.

20. In situ Hybridization Detection System. Available from: http://www. maximbiotech.com.

21. Camorlinga-Ponce M, Romo C, Gonzalez-Valencia G, Munoz O, Torres J. Topographical localisation of cagA positive and cagA negative Helicobacter pylori strains in the gastric mucosa; An in situ hybridisation study. J Clin Pathol 2004;57(8):822-8

22. Vilaichone RK, Mahachai V, Shiota S, Uchida T, Ratanachu-ek T, Tshering L, et al. Extremely high prevalence of Helicobacter pylori infection in Bhutan. World J Gastroenterol 2013;19(18):2806.

23. Al-Ezzy AI. In situ nick end labeling as a molecular immunopathological indicator for the severity of DNA fragmentationand gastroduodenal tissue damage among H. Pylori Cag A positive patients. Indian J Sci Technol 2016;9(2):1-11

24. Sasidharan S, Ghayethry B, Ravichandran M, Latha LY, Lachumy SJ, Leng KM, et al. Prevalence of Helicobacter pylori infection among patients referred for endoscopy: Gender and ethnic differences in Kedah, Malaysia. Asian Pac J Trop Dis 2012;2(1):55-9.

25. Al-Ezzy AIA. Evaluation of endoscopy based H. Pylori diagnostic techniques in Iraqi patients with upper gastrointestinal disorders. IJST 2016;9(22):1-10

26. Morales-Fuentes G, Zarate-Osorno A, Quinez-Urrego E, AntonioManrique M, Martnez-Garcla C, Figueroa-Barojas P, et al. p53 expression in the gastric mucosa of patients infected with Helicobacter pylori. Rev Gastroenterol Mex 2013;78(1):12-20.

27. Krashias G, Bashiardes S, Potamitou A, Potamitis GS, Christodoulou C. Prevalence of Helicobacter pylori cagA and vacA genes in cypriot patients. J Infect Dev Ctries 2013, 7(9):642-50.

28. Secka O, Antonio M, Berg DE, Tapgun M, Bottomley C, Thomas V, et al. Mixed infection with cagA positive and cagA negative strains of Helicobacter pylori lowers disease burden in the Gambia. PLoS One 2011;6(11):e27954.

29. Lidia C, Taulescu M, Dan LD. Helicobacter pylori in Romania: Epidemiology, diagnosis and treatment. Helicobacter pylori: A Worldwide Perspective 2014. Oak Park, IL USA: Science Publishers; 2014. p. 183-201.

30. Lee SY. Helicobacter pylori in South-Eastern Asia. Helicobacter pylori: A Worldwide Perspective 2014. Bentham Science; 2014. p. 92-129.

31. Rokkas T. Helicobacter pylori in Greece: Epidemiology, Diagnosis, and Treatment. Helicobacter pylori: A Worldwide Perspective 2014. Bentham Science; 2014. p. 202-15.

32. Xu XQ, Wang ZH, Liao JX, Chen XY, Liu WZ, Xiao SD, Lu H. Predictive value of neutrophil infiltration as a marker of Helicobacter pylori infection. World J Gastroenterol 2012;18(36):5101.

33. Rolig AS, Cech C, Ahler E, Carter JE, Ottemann KM. The degree of Helicobacter pylori-triggered inflammation is manipulated by preinfection host microbiota. Infect Immun 2013;81(5):1382-9.

34. Pity IS, Baizeed AM. Identification of Helicobacter pylori in gastric biopsies of patients with chronic gastritis: Histopathological and immunohistochemical study. Duhok Med J 2011;5(1):69-77.

35. Al-Ezzy AI. Immunomodulatory effect of H. Pylori Cag A genotype and gastric hormones on gastric versus inflammatory cells fas gene expression in Iraqi patients with gastroduodenal disorders. Open Access Maced J Med Sci 2016;4(3):364-73.

36. Varbanova M, Malfertheiner P. Bacterial load and degree of gastric mucosal inflammation in Helicobacter pylori infection. Dig Dis 2011:29(6):592-9

37. Nai GA, Parizi AC, Barbosa RL. Association between Helicobacter pylori concentration and the combining frequency of histopathological findings in gastric biopsies specimens. Arq Gastroenterol 2007;44(3):240-3

38. Aryana K, Reza KM, Zakavi SR, Sadeghian MH, Akbari H. Association of Helicobacter pylori infection with the Lewis and $\mathrm{ABO}$ blood groups in dyspeptic patients. Niger Med J 2013;54(3):196-9.

39. Argent RH, Thomas RJ, Letley DP, Rittig MG, Hardie KR, Atherton JC. Functional association between the Helicobacter pylori virulence factors VacA and CagA. J Med Microbiol 2008;57(2):145-50.

40. Aspholm M. Adaptation of Helicobacter Pylori Adherence Properties in Promotion of Host Tropism and Inflammatory Disease. Sweden: UMEÃ University; 2004.

41. Hofner P, Gyulai Z, Kiss ZF, Tiszai A, Tiszlavicz L, Toth G, et al. Genetic polymorphisms of NOD1 and IL8, but not polymorphisms of TLR4 genes, are associated with Helicobacter pylori induced duodenal 
ulcer and gastritis. Helicobacter 2007;12(2):124-31.

42. Ihan A, Pinchuk IV, Beswick EJ. Inflammation, immunity, and vaccines for Helicobacter pylori infection. Helicobacter 2012;17(1):16-21.

43. Hofner P, Gyulai Z, Kiss ZF, Tiszai A, Tiszlavicz L, Toth G, et al. Genetic polymorphisms of NOD1 and ILâ€ 8, but not polymorphisms of TLR4 genes, are associated with Helicobacter pylori induced duodenal ulcer and gastritis. Helicobacter 2007;12(2):124-31.

44. Andrei V, Gudkov KV, Elena AK. Inflammation and p53: A tale of two stresses. Gene Cancer 2011;2(4):503-16.

45. Deng X, Gao F, Flagg T, Anderson J, May WS. Bcl2's flexible loop domain regulates p53 binding and survival. Mol Cell Biol 2006;26(12):4421-34

46. Olivares D, Gisbert JP, Pajares JM. Helicobacter pylori infection and gastric mucosal epithelial cell apoptosis. Rev Esp Enferm Dig 2005;97(7):505-20.

47. Mimuro H, Suzuki T, Nagai S, Rieder G, Suzuki M, Nagai T, et al. Helicobacter pylori dampens gut epithelial self-renewal by inhibiting apoptosis, a bacterial strategy to enhance colonization of the stomach. Cell Host Microbe 2007;2(4):250-63.

48. Twaij AD. Invasive and Non Invasive Methods for the Detection of H. pylori With Some Molecular Aspects of its Pathogenesis (Bax mRNA by I.S. H. and Bcl-2 by I.H.C.). Ph.D. Thesis. College of Medicine, Al-Nahrain University; 2006.

49. Liu HF, Liu WW, Wang GA, Teng XC. Effect of Helicobacter pylori infection on bax protein expression in patients with gastric precancerous lesions. World J Gastroenterol 2005;11(37):5899-901.

50. Hasson HA, Hassan HA, Hassan BA, Ali TW. Bcl-2 expression in CagA strain H. Pylori gastritis (Immunohistochemical and in situ hybridization study). Iraqi Postgrad Med J 2012;11(1):71-5.

51. Bartchewsky JW, Martini MR, Squassoni AC, Alvarez MC, Ladeira MS, Salvatore DM, et al. Effects of Helicobacter pylori infection on the expressions of bax and $\mathrm{Bcl}-2$ in patients with chronic gastritis and gastric cancer. Dig Dis Sci 2010;55(1):111-16.

52. Chu SH, Lim JW, Kim DG, Lee ES, Kim KH, Kim H. Down-regulation of $\mathrm{Bcl}-2$ is mediated by NF- $\mathrm{kB}$ activation in Helicobacter pyloriinduced apoptosis of gastric epithelial cells. Scand J Gastroenterol 2011;46(2):148-55.

53. Al-Ezzy AI. Molecular and immunopathological role of nuclear factor $\mathrm{k} \mathrm{b}$ detected by in situ hybridization in pathogenesis of chronic atrophic gastritis in Iraqi patients. Int J Adv Res 2014;2(1):67-78

54. Pham KT, Fischer W. Helicobacter pylori utilizes DNA shuffling to modulate the gastric inflammatory response. Future Microbiol 2013:8(7):835-8

55. Witkowska M, Smolewski P. Helicobacter pylori infection, chronic inflammation, and genomic transformations in gastric MALT lymphoma. Mediators Inflamm 2013;2013:1-8.

56. Lynch DA, Mapstone NP, Clarke AM, Jackson P, Moayyedi P, Dixon MF. Correlation between epithelial cell proliferation and histological grading in gastric mucosa. J Clin Pathol 1999;52(5):367-71.

57. Kohda K, Tanaka K, Aiba Y, Yasuda M, Miwa T, Koga Y. Role of apoptosis induced in Helicobacter pylori infection in the development of duodenal ulcer. Gut 1999;44(4):456-62.

58. Rokkas T, Ladas S, Liatsos C, Petridou E, Papatheodorou G, Theocharis S, et al. Relationship of H. Pylori cag A status to gastric cell proliferation and apoptosis. Dig Dis Sci 1999;44(3):487-93.

59. Suzuki H, Suzuki M, Mori M, Kitahora T, Yokoyama H, Miura S, et al. Augmented levels of gastric mucosal leucocyte activation by infection with cagA gene positive Helicobacter pylori. J Gastroenterology Hepatol 1998;13(3):294-300.

60. Robinson K, Argent RH, Atherton JC. The inflammatory and immune response to Helicobacter pylori infection. Best Pract Res Clin Gastroenterol 2007;21(2):237-59. 